Gillman, J. \& Gillman, T. (195 I). Perspectives in Human Malmutrition. New York: Grune and Stratton. Harper, A. E. \& Katayama, M. C. (1953). F. Nutr. 49, 261.

Henry, K. M. \& Kon, S. K. (1950). Biochim. biophys. Acta, 5, 455.

Lea, C. H. \& Hannan, R. S. (1950). Biochim. biophys. Acta, 4, 5 I8.

Lofland, H. B. Jr., Clarkson, T. B. \& Goodman, H. O. (r96r). Circulat. Res. 9, 9 rg.

Munro, H. N. (1949), F. Nutr. 39, 375.

Munro, H. N., Black, J. G. \& Thomson, W. S. T. (1959). Brit. $\mathcal{F}$. Nutr. I3, 475

Platt, B. S., Miller, D. S. \& Payne, P. R. (196I). In Recent Advances in Human Nutrition, p. 35 I. [J. F. Brock, editor.] I,ondon: Churchill.

\title{
Dietary factors affecting energy utilization
}

\section{By K. L. BLAXTER, Hannah Dairy Research Institute, Ayr}

The most common nutritional experiment is the comparative feeding trial. Two groups of animals are given free access to two diets and their gains in weight recorded and compared. Differences in weight gain in such experiments can be very large. In thiamine deficiency in rats, for example, deficient animals may weigh less at the end than at the beginning of the trial though the control rats have doubled or trebled their weight. In such an experiment the heats of combustion of the thiamine-deficient diet and the control diet per unit weight are virtually identical. It is thus possible to state that thiamine deficiency has prevented the animals making full use of the calories supplied as food. As the deficiency proceeds, however, thiamine-deficient animals eat less food. Although their diets may be isocaloric per unit weight, deficient and control animals do not consume the same number of calories. By pair-feeding the animals, thus restricting the intake of food by the control animals to that consumed by the thiamine-deficient animals, it is found that both the control animals and the deficient ones lose weight or, if the deficiency is mild, gain weight only slowly. The thiamine-deficient animals usually but not invariably still weigh less than the control animals (Voris, Black, Swift \& French, 1942; Pecora \& Highman, r953; van Eys, I96r).

Table I. Effect of mild thiamine deficiency on weight gain and energy retention by male rats (Voris et al. 1942; Voris $\Xi^{\circ}$ Moore, I943)

\begin{tabular}{|c|c|c|c|c|c|c|c|}
\hline \multirow[b]{3}{*}{ Group } & \multirow{3}{*}{$\begin{array}{c}\text { Food } \\
\text { eaten in } \\
\text { Io weeks } \\
\text { (g) }\end{array}$} & \multirow{3}{*}{$\begin{array}{l}\text { Carcass } \\
\text { weight } \\
\text { gain } \\
\text { (g) }\end{array}$} & & & & \multicolumn{2}{|c|}{ Fat in gain } \\
\hline & & & \multicolumn{3}{|c|}{ Gain of carcass } & & Ratio, \\
\hline & & & $\begin{array}{l}\text { Fat } \\
\text { (g) }\end{array}$ & $\begin{array}{c}\text { Protein } \\
\text { (g) }\end{array}$ & $\underset{\text { (kcal) }}{\text { Energy }}$ & $\begin{array}{c}\% \text { of } \\
\text { body-weight }\end{array}$ & $\begin{array}{l}\text { total } \\
\text { calories }\end{array}$ \\
\hline & 549 & 145 & II.9 & $32 \cdot 7 \pm 1 \cdot 6$ & 294 & $8 \cdot 2$ & 38 \\
\hline & 550 & 144 & $15 \cdot 2$ & $3 \mathrm{I} \cdot 8 \pm \mathrm{r} \cdot 4$ & 319 & 10.5 & 44 \\
\hline nrestricted controls & 755 & 166 & 40.7 & $30.4 \pm 0.3$ & 549 & $24 \cdot 7$ & 69 \\
\hline
\end{tabular}

The results of a pair-feeding experiment in which a mild thiamine deficiency was produced are given in Table $I$. In these experiments all the animals gained about the same amount of protein. Protein metabolism was thus unimpaired, a conclusion supported by the fact that thiamine-deficient rats can still manufacture antibodies (Axelrod \& Hopper, 1960). The amount of fat gained by the thiamine-deficient rats 
was $22 \%$ less than that gained by the pair-fed controls. The number of calories retained was $8 \%$ less than retained by pair-fed controls. Such data show unequivocally that the normal processes of energy transfer have been impaired by the deficiency since with the same number of calories ingested the thiamine-deficient animals retained less energy. The paired-feeding technique, however, discounts entirely the major factor accounting for the lack of energy storage by deficient animals, namely the voluntary reduction of the intake of food. As will be discussed later, reduction of food intake is probably the major way in which changes in dietary composition affect energy utilization.

With this important reservation in mind, differences in the efficiency of dietary energy utilization can be said to exist if diets providing the same number of calories (heat of combustion) promote different storages of energy in the body. Such differences in storage could arise from differences in the loss of energy as the heat of combustion of the faeces or of the urine or they could arise from differences in the heat produced by the animal. This definition though correct is not satisfactory in many instances because we already know that losses of energy in faeces and urine vary with the nature of the diet and can be predicted. The faecal loss of energy varies with the nature of the diet in a clearly recognizable way. With herbivores the losses in faeces vary from $15 \%$ of the calories ingested when cereals supply the energy to as much as $60 \%$ when the calories are supplied as straw. With simple-stomached animals some structural carbohydrates are not digested at all and faecal losses of energy on habitual diets can depart widely from an average value of $5 \%$. Similarly, the losses of energy in urine vary with the protein content of the diet for the nitrogen is excreted mainly as urea with a heat of combustion of $5.6 \mathrm{kcal} / \mathrm{g} \mathrm{N}$. In herbivores, the urinary losses of energy vary widely with the nature of attributes of the diet other than protein. As much as $40 \mathrm{kcal} / \mathrm{g} \mathrm{N}$ are found in the urine with some diets, the high ratio being largely accounted for by excretion of large quantities of hippuric acid and glucuronates.

These well-established losses are recognized in the common use in human and small-animal nutrition of the Rubner or Atwater calorie as a unit, that is by the application to dietary available carbohydrate, protein and fat of factors which are about 4,4 and $9 \mathrm{kcal} / \mathrm{g}$. They are recognized in the nutrition of herbivores by employing listed values for the digested energy or the metabolizable energy of individual foods when formulating rations which are isocaloric in the sense that they are calculated to provide the tissue with the same number of calories. Diets calculated to be isocaloric in this way, for the very reason that the factors are average ones, can in fact provide different amounts of metabolizable energy. With herbivores, even the most accurate methods of prediction of metabolizable energy based on chemical analysis of the complete ration do not achieve a precision greater than $\pm 4 \%$ (Armstrong, Blaxter \& Waite, 1964) and with most human and rat diets the error is probably of the same order. With bizarre diets differences could be much greater.

The effects of specific deficiency of dietary essentials on the faecal loss of energy are usually small and insufficient to account for discrepancies in the energy retention of pair-fed animals, a possible exception being vitamin A deficiency (Ritzman, 
Colovos, Keener \& Teeri, 1945). Losses of energy in urine, however, can be augmented by dietary deficiency. In thiamine deficiency, for example, rats excrete daily up to Io $\mathrm{mg}$ pyruvic acid (Banerji \& Harris, I 939), $20 \mathrm{mg}$ lactic acid (van Eys, Judge, Judd, Hill, Bozian \& Abrahams, I962) and 3 mg glyoxylic acid (Liang, I 962) together with smaller amounts of keto acids other than pyruvic. The heat of combustion of these compounds amounts to $0.1-0.2 \mathrm{kcal} /$ day. This additional loss of energy in urine by thiamine-deficient animals is considerably less than $1 \%$ of the intake of energy in food and can account for only a part of the difference in energy retention noted in Table I for rats mildly deficient in thiamine. Even if thiaminedeficient animals excreted these compounds at a maximal rate throughout the deficiency - a doubtful supposition - at the most a quarter of the discrepancy in the energy retentions of the pair-fed animals could be accounted for. A further example of the increase in loss of energy in urine when isocaloric diets are given is the ketosis which develops in rats on diets very high in fat or on diets containing dried horse meat rather than casein as the source of protein (Stewart \& Young, 1959). With the latter diet ketone-body excretion increased from $0.2 \mathrm{mg}$ to as much as $60 \mathrm{mg} \beta$ hydroxybutyric acid $/ 24 \mathrm{~h}$ on isocaloric substitution of horse meat for casein, and the effect could be elicited by $300 \mathrm{mg}$ of a lipid extracted from the meat. The amount of ketones excreted by the ketotic rats represents a daily loss of $0.27 \mathrm{kcal}$, which is again less than $\mathrm{I} \%$ of the heat of combustion of the diet.

In general it appears that, in deficiency states in which intermediary compounds are excreted in the urine, the amounts excreted are small relative both to the calories in the diet and to the total turnover of the compound in the tissues. The amount excreted can be regarded as an unavoidable spill-over. This is true of both thiamine deficiency (Jones \& de Angeli, 1960) and fat-induced ketosis (Mayes, 1959). Changes in the magnitude of the urinary loss of energy are usually not sufficient to account for a low retention of energy in specific dietary deficiencies, though they are excellent indicators of metabolic abnormality.

The final route of energy loss to be considered in an examination of the determinants of the efficiency of energy utilization in the restricted sense we have defined is the loss of energy as heat. It is usual to divide the heat production of an animal into two components, the heat of the basal metabolism and the heat due to the calorigenic action of food, that is a constant minimum amount that can be measured by starving the animal and an amount that is proportional to the food intake and can be measured by determining heat production at two or more levels of feeding (Kleiber, 1945-6). A more useful division is to regard the heat production of an animal as consisting of the heat equivalent of the work done by the cells and organs of the body whether it is mechanical, osmotic or electrochemical in nature and of the energy lost as heat when metabolites are oxidized to provide the energy to undertake these activities. This division is more useful since the basal heat measurement is of mixed significance: during fasting energy is provided for work done by the body by an oxidation of the fat and protein of the body cells.

To deal with the most obvious aspect first, diet can alter the amount of voluntary activity the animal undertakes. An example is the behavioural pattern of the thiamine- 
deficient animal which cowers in a corner while its pair-fed control, given less food than it would like, is invariably searching for food. From this it could be inferred that thiamine deficiency decreases voluntary muscle activity and hence heat production. Involuntary muscular activity may also be induced by dietary change. In experimental magnesium deficiency, for example, a deficiency in which heat production is markedly increased, the increase can be ascribed to an increase in muscular activity due to mild tetany (Blaxter \& Rook, I955). The calorigenic effect of food is unaltered. The same explanation appears true of experimental calcium deficiency in the rat, for the increase in heat production is constant irrespective of the amount of food given (Kleiber, Boelter \& Greenberg, 1940). Increases in heat production due to additional work output probably also occur when diets are given that produce anaemia because the work done in the transport of oxygen to the tissues necessarily increases.

The ability of different foods to act as energy sources for meeting body demands is best approached by considering the energy transfers occurring when a compound has been absorbed and is oxidized in the body. When I mole of glucose is oxidized to carbon dioxide and water by the isolated tissues of a normal animal and its route of oxidation is the Embden-Meyerhof pathway and the tricarboxylic acid cycle, the yield of free energy potentially of use to the animal can be calculated to be equivalent to the synthesis of 38 moles of ATP from ADP. The formation of the pyrophosphate bond of ATP is a convenient way of summarizing the energy yielded by biological oxidations because the pyrophosphate bond or high-energy bond appears to be the energy currency of the body. The heat of combustion of 1 mole of glucose is 673 kcal. It follows that when glucose is the substrate $673 \div 38=17 \cdot 7 \mathrm{kcal}$ must be used to manufacture one pyrophosphate bond. When a long-chain fatty acid such as stearic acid is oxidized to carbon dioxide and water via the Lynen spiral and the tricarboxylic acid cycle, the yield of pyrophosphate bond energy is equivalent to the formation of 146 moles of ATP from ADP. With a heat of combustion of $2712 \mathrm{kcal} / \mathrm{mole}$ stearic acid, this is equivalent to the oxidation of $18.6 \mathrm{kcal}$ stearic acid per pyrophosphate bond formed. As the chain length of the acid decreases, so the number of calories required to synthesize a pyrophosphate bond increases. With acetic acid, for example, the number of calories required rises to $20.9 \mathrm{kcal}$ per pyrophosphate bond. Similar calculations can be made for amino acids and such figures show that, for the incomplete dissimilation of a protein such as casein and the excretion of the nitrogen it contains as urea, the number of kcal of protein expressed as metabolizable energy required for the synthesis of I mole ATP from ADP is about 22.

These calculations show that to provide one high-energy bond different amounts of energy measured as heat of combustion of the compound have to be provided by different substrates, and the calculations are fully supported by experiment (Krebs, 1960; Blaxter, 1962). The ruminant absorbing most of its carbohydrate as steamvolatile fatty acids requires about $15 \%$ more energy measured as heat of combustion of the absorbed products to accomplish the same amount of work as does an animal absorbing its carbohydrate as glucose. It follows that diets isocaloric in terms of metabolizable energy are not necessarily isocaloric in terms of their ability to provide 
energy to the body to do essential work that involves expenditure of pyrophosphatebond energy.

The specific dynamic effect of food (SDE) determined in an animal that is not synthesizing new body constituents is a measure of this disparity in the calorie equivalents of high-energy bonds from compound to compound. The SDE is in fact a measure of the ability of a diet to replace the fat and protein of the body as a source of free energy for the essential work of maintaining its integrity.

Synthesis of fat and protein in the body can be approached in a similar way. It is at once evident that a much greater variation in the overall energy costs of performing syntheses and hence variation in heat production can be expected than is apparent when compounds are oxidized to provide energy for work. With fat deposition, for example, some dietary fatty acids can be directly incorporated in the triglycerides of the tissues, the only energy cost involved in the synthesis being their transport and esterification. When carbohydrate is the source of the carbon for fat synthesis, degradation to a 2-carbon compound and stepwise synthesis of the fatty acid chain takes place. It would be expected therefore that the heat production in an animal gaining body fat from a diet of fat would be less than in one synthesizing fat from carbohydrate. That this is so is shown in recent experiments by Nehring \& Schiemann (196I) which fully confirm earlier experiments by Fingerling (Fingerling, Köhler \& Reinhardt, I9I2-I3; Fingerling, Eisenkolbe, Hientzsch, Just \& Knauth, I938).

Table 2. Increase in heat production when body fat is synthesized from sucrose or from arachis oil in the rat and pig (Nehring $\mathcal{F}^{\circ}$ Schiemann, 1961)

\begin{tabular}{|c|c|c|c|}
\hline Food & Animal & $\begin{array}{l}\text { Fat synthesized } \\
\text { (kcal/roo kcal } \\
\text { metabolizable } \\
\text { energy) }\end{array}$ & $\begin{array}{l}\text { Heat produced } \\
\text { (kcal/Ioo kcal } \\
\text { fat synthesized) }\end{array}$ \\
\hline \multirow[t]{2}{*}{ Arachis oil } & Rat & $83 \cdot 1 \pm I \cdot 5$ & $20 \cdot 3$ \\
\hline & Pig & $85 \cdot 9 \pm r \cdot 3$ & $16 \cdot 4$ \\
\hline \multirow[t]{2}{*}{ Sucrose } & Rat & $73 \cdot 3 \pm 1 \cdot 6$ & $36 \cdot 4$ \\
\hline & Pig & $74 \cdot 6+1 \cdot 8$ & $34 \cdot I$ \\
\hline
\end{tabular}

Table 2 shows that, when rats synthesize $100 \mathrm{kcal}$ fat from sucrose, heat production is $80 \%$ greater than it is when the source of energy is arachis oil. With pigs, which probably incorporate more fatty acids directly into body lipid than do rats, the heat increment of lipogenesis is twice as great with sucrose as it is with arachis oil, and in rabbits (Nehring \& Schiemann, I96I) it appears to be even greater than it is with pigs.

In these examples, sugar was providing the free energy for the synthesis of longchain fatty acids and also the carbon of the acids, in the form of acetyl coenzyme A. If the carbon is provided as acetic acid, the energy cost of the synthesis may be expected to be greater than when carbon is supplied as glucose since energy has to be expended to synthesize the coenzyme A derivative. Furthermore, fat synthesis from 2-carbon compounds demands a reduced coenzyme (reduced nicotinamide adenine dinucleotide phosphate $\left(\mathrm{NADPH}_{2}\right)$ ) which is largely but not entirely formed by dissimilation of carbohydrate by the pentose phosphate cycle. In other words, to 
synthesize fat from 2-carbon compounds involves the obligatory generation of a particular energy-carrying molecule, mainly from carbohydrate or carbohydrate precursors. For these reasons fat synthesis in ruminants which receive most of their energy as steam-volatile fatty acids produces more heat per $100 \mathrm{kcal}$ fat synthesized than in non-ruminants which receive most of their energy as glucose, and the amount of heat produced by ruminants varies with the proportions of $\mathrm{C}_{2}$ and $\mathrm{C}_{4}$ acids to $\mathrm{C}_{3}$ acids, glucose and non-ketogenic amino acids in the mixture of these substances they absorb.

The results given in Table 3 show that the increase in heat production per 100 kcal fat synthesized from glucose in sheep was much the same as the values obtained for sucrose in pigs and rats (see Table 2 ). When fat was synthesized from a mixture of steam-volatile acids in which acetic acid predominated, heat production in $\mathrm{kcal} / \mathrm{I} 00$ kcal fat synthesized increased sixfold. Table 3 also shows, and this is supported by experiments with rats (Kriss, Forbes \& Miller, 1934), that considerably more heat is produced when casein is the source of energy and carbon for fat synthesis than when glucose is the source.

Table 3. Increase in heat production when body fat is synthesized in ruminants

\begin{tabular}{|c|c|c|c|}
\hline Source of energy & $\begin{array}{c}\text { Fat synthesized } \\
\text { (kcal/ıoo kcal } \\
\text { metabolizable } \\
\text { energy) }\end{array}$ & $\begin{array}{l}\text { Heat produced } \\
\text { (kcal/ roo kcal } \\
\text { fat synthesized) }\end{array}$ & Reference \\
\hline Glucose* & $72 \cdot 8 \pm 3 \cdot 1$ & 37 & $\begin{array}{l}\text { Armstrong, Blaxter \& Graham } \\
\quad(1960)\end{array}$ \\
\hline $\begin{array}{l}\text { Steam-volatile fatty acid mixture } \\
\text { in which acetic acid predomin- } \\
\text { ates }\end{array}$ & $3 I \cdot 8 \pm I \cdot 8$ & 214 & $\begin{array}{l}\text { Armstrong, Blaxter, Graham \& } \\
\text { Wainman (1958) }\end{array}$ \\
\hline $\begin{array}{l}\text { Steam-volatile fatty acid mixture } \\
\text { in which propionic acid pre- } \\
\text { dominates }\end{array}$ & $58 \cdot 1 \pm 1 \cdot 2$ & 72 & Armstrong et al. (1958) \\
\hline Casein* & $64 \cdot 7 \pm 3 \cdot 2$ & 55 & Blaxter \& Martin (1962) \\
\hline
\end{tabular}

*Precautions were taken to avoid fermentation of the glucose or the casein by rumen microorganisms: the results therefore refer to glucose absorbed as such and to the amino acids of casein.

Similar arguments can be applied to protein synthesis: the energy cost of incorporation of a non-essential amino acid from diet into body protein is likely to be less than if the corresponding keto acid is synthesized from other dietary constituents and then aminated. The conclusion that can be drawn from these considerations is that heat losses may be expected to vary fairly widely with the nature of the diet and that this potential variation will be less when no net synthesis of fat and protein is taking place than when synthesis occurs. The assumption that diets that are complete in all essentials and are isocaloric with respect to metabolizable energy but vary in composition with respect to the proportions of fat, carbohydrate and protein will promote the same gains of weight or of energy is certainly not correct.

Vitamins of the B complex act through the enzymes of which they form the prosthetic groups. Diminution in enzyme concentration can be expected to result in a partial block of the particular enzyme system concerned; intermediary products 
accumulate, their concentrations change and elicit compensatory changes in enzyme systems often far removed from the primary site of action. These changes may be complex, and again thiamine deficiency may be taken as example.

The work of Peters (1936) and of Lohmann \& Schuster (1937) showed that thiamine as pyrophosphate is a part of the enzyme that decarboxylates pyruvate, and it was long thought that a decrease in concentration of this enzyme was responsible for the signs of thiamine deficiency and that the metabolic defect was due to an inability of carbohydrate to enter the tricarboxylic acid cycle. This idea was supported by the observation that an increase in the proportion of fat in the diet had a sparing action on thiamine (Evans \& Lepkovsky, r 929), for dissimilation of fatty acids does not result in pyruvate formation. In addition, Wright \& Scott (1954) showed that in vitro the oxidation of pyruvate was more depressed by thiamine deficiency than oxidation of $\alpha$-oxoglutarate, thiamine pyrophosphate being a cofactor for this enzyme also. Unfortunately there are several difficulties in accepting this interpretation. Firstly, in vivo the deficient rat does not appear to have an impaired ability to oxidize ${ }^{14} \mathrm{C}$-labelled pyruvic and lactic acids (Jones \& de Angeli, r960); secondly, the accumulation of pyruvate is small relative to the amounts formed; thirdly, another metabolite first thought to be methylglyoxal (Salem, 1954) but since identified as glyoxylic acid (Liang, I962) accumulates as well as pyruvate and, lastly, there are discrepancies between the syndromes produced by the thiamine analogues oxythiamine and pyrithiamine (Cerecedo, Soodak \& Eusebi, I95I). Transketolase also needs thiamine pyrophosphate (Horecker \& Smyrniotis, I 953), and evidence suggests that in erythrocytes this enzyme is non-functional at a very early stage in thiamine deficiency (Brin, Shohet \& Davidson, I958). One explanation of these observations is that fat synthesis is depressed in thiamine-deficient animals largely because of the involvement of thiamine as pyrophosphate in the pentose phosphate cycle. The accumulation of pyruvate can then be regarded as evidence of an increased passage of carbohydrate through glycolytic pathways with consequent greater loss of energy as heat. Whether this is the correct interpretation is not known.

From this work it appears as a generalization that, in specific dietary deficiencies and excesses, animals reduce the load on the enzyme systems affected by the deficiency. Alternative metabolic pathways of dissimilation or synthesis, some of which are not as efficient in the transfer of energy, may be used to avoid the block, but in general the primary method employed to reduce the load is to reduce food intake.

Table 4. Effect of cold on food intake and weight gain in thiamine deficiency in rats (Vaughan E० Vaughan, 1957)

\begin{tabular}{|c|c|c|c|c|c|}
\hline \multirow{2}{*}{$\begin{array}{l}\text { Environmental } \\
\text { temperature } \\
\left({ }^{\circ} \mathrm{C}\right)\end{array}$} & \multirow{2}{*}{\multicolumn{2}{|c|}{$\begin{array}{l}\text { Food intake (g/18 } \\
\text { days) when thiamine } \\
\text { content of food was: } \\
0.3 \mu \mathrm{g} / \mathrm{g}\end{array}$}} & \multicolumn{2}{|c|}{$\begin{array}{l}\text { Body-weight change } \\
\text { (g/1 } 8 \text { days) when } \\
\text { thiamine content of } \\
\text { food was: }\end{array}$} & \multirow[t]{2}{*}{$\begin{array}{l}\text { Difference } \\
\text { in change } \\
\text { in I } 8 \text { days } \\
\text { due to } \\
\text { deficiency }\end{array}$} \\
\hline & & & $0.3 \mu \mathrm{g} / \mathrm{g}$ & $2 \cdot 0 \mu \mathrm{g} / \mathrm{g}$ & \\
\hline 5 & 253 & 436 & -69 & +26 & -95 \\
\hline $\begin{array}{c}25 \\
\text { Net change }\end{array}$ & 97 & 284 & -89 & +55 & -144 \\
\hline due to cold & +156 & +152 & +20 & -29 & -49 \\
\hline
\end{tabular}


This generalization has far-reaching implications with respect to the neural control of food intake, and is an aspect of food intake regulation much neglected. It is known, for example, that in the rat exposure to cold increases voluntary food intake. Exposure to cold of both thiamine-deficient animals and those given thiamine indicates that food intake increases in both by precisely the same amount (Vaughan \& Vaughan, 1957). These results are given in Table 4 . This table shows that the increase in food intake by thiamine-deficient rats and controls in response to cold was in absolute terms the same. It was relatively much greater for the deficient rats, so the effects of thiamine deficiency as judged by differences in weight gain were less at $5^{\circ}$ than at $25^{\circ}$. It does not follow from this experiment that in thiamine deficiency no impairment of the mechanisms involved in providing free energy for the muscular work of shivering occurs but only that the thiamine-deficient rat can still completely dissimilate large amounts of food with the liberation of heat. This suggests that pathways of synthesis rather than dissimilation are affected.

Similar results have been obtained in deficiencies of riboflavine (Vaughan \& Vaughan, I959), pantothenic acid (Vaughan \& Vaughan, I960) and pyridoxine (Vaughan \& Vaughan, 1961). When dietary imbalance is caused by the addition of amino acids, gain and food intake both decrease. Cold again stimulates food intake and the stimulation tends to be greater in absolute terms for rats receiving the unbalanced diet (Klain, Vaughan \& Vaughan, I962). Growth on diets unbalanced with respect to amino acids is therefore enhanced by exposure to cold. That the same is true of protein-deficient diets has been shown by Andik, Donhoffer, Farkas $\&$ Schmidt ( 1963 ). Exposure to cold of rats given ad lib. access to a diet containing $4.3 \%$ protein resulted in resumption of growth. The same diet given in the warm led to loss in weight and death. Force-feeding with unbalanced mixtures of amino acids in the warm also leads to death (Deshpande, Harper \& Elvehjem, I958). This shows that the effect of cold on growth must be explained in terms of an increased energy expenditure due to the work of shivering which does not involve protein, and a change in the economy of the animal as between energy expenditure and net synthesis.

\section{REFERENCES}

Andik, I., Donhoffer, Sz., Farkas, M. \& Schmidt, P. (1963). Brit. F. Nutr. 17, 257.

Armstrong, D. G., Blaxter, K. L. \& Graham, N. McC. (I960). Proc. Nutr. Soc. 19, xxxi.

Armstrong, D. G., Blaxter, K. I., Graham, N. McC. \& Wainman, F. W. (I958). Brit. F. Nutr. $12,177$.

Armstrong, D. G., Blaxter, K. L. \& Waite, R. (1964). F. agric. Sci. (In the Press.)

Axelrod, A. E. \& Hopper, S. (1960). F. Nutr. 72, 325.

Banerji, G. G. \& Harris, L. J. (1939). Biochem. F. 33, 1346.

Blaxter, K. L. (1962). The Energy Metabolism of Ruminants. London: Hutchinson.

Blaxter, K. L. \& Martin, A. K. (1962). Brit. F. Nutr. 16, 397.

Blaxter, K. L. \& Rook, J. A. F. (1955). Brit. F. Nutr. 9, I21.

Brin, M., Shohet, S. S. \& Davidson, C. S. (r958). F. biol. Chem. 230, 3 I9.

Cerecedo, L. R., Soodak, M. \& Eusebi, A. J. (I95I) F. biol. Chem. 189, 293.

Deshpande, P. D., Harper, A. E. \& Elvehjem, C. A. (r958). F. biol. Chem. 230, 335.

Evans, H. M. \& Lepkovsky, S. (1929). F. biol. Chem. 83, 269.

Fingerling, G., Eisenkolbe, P., Hientzsch, B., Just, M. \& Knauth, G. (1938). Z. Tierernähr. 1, I93.

Fingerling, G., Köhler, A. \& Reinhardt, F. (1912-13). Landw. VersSta. 84, I 49.

Horecker, B. L. \& Smyrniotis, P. Z. (1953). Y. Amer. chem. Soc. 75, 1009.

Jones, J. H. \& de Angeli, E. (1960). F. Nutr. 7o, 537. 
Klain, G. J., Vaughan, D. A. \& Vaughan, L. N. (1962). F. Nutr. 78, 359.

Kleiber, M. (1945-6). Nutr. Abstr. Rev. I5, 207.

Kleiber, M., Boelter, D. D. \& Greenberg, D. M. (1940). F. Nutr. 19, 5 I 7.

Krebs, H. A. (1960). Arzneimittel-Forsch. 10, 369.

Kriss, M., Forbes, E. B. \& Miller, R. C. (1934). f. Nutr. 8, 509.

Liang, C.-C. (1962). Biochem. F. 82, 429.

Lohmann, K. \& Schuster, P. (1937). Biochem. Z. 294, 188.

Mayes, P. A. (I959). Biochem. 7. 71, 459.

Nehring, M. \& Schiemann, R. (I96I). Int. Congr. Anim. Prod. vils, Hamburg, Vol. 3, p. 242.

Pecora, L. J. \& Highman, B. (1953). F. Nutr. 5r, 2 r9.

Peters, R. A. (1936). Lancet, i, I I6r.

Ritzman, E. G., Colovos, N. F., Keener, H. A. \& 'Teeri, A. E. (I945). Tech. Bull. N.H. agric. Exp. Sta. no. 87 .

Salem, H. M. (1954). Biochem. F. 57, 227.

Stewart, H. B. \& Young, F. G. (I959). Biochem. F. 72, 60.

van Eys, J. (1961). F. Nutr. 73, 403.

van Eys, J., Judge, M. A., Judd, J., Hill, W., Bozian, R. C. \& Abrahams, S. (1962). F. Nutr. 76, 375.

Vaughan, D. A. \& Vaughan, I. N. (1957). F. Nutr. 63, 417.

Vaughan, D. A. \& Vaughan, L. N. (1959). \%. Nutr. 68, 485 .

Vaughan, D. A. \& Vaughan, L. N. (1960). F. Nutr. 70, 77.

Vaughan, D. A. \& Vaughan, L. N. (I96r). F. Nutr. 73, 53 .

Voris, L., Black, A., Swift, R. W. \& French, C. E. (1942). J. Nutr. 23, 555 .

Voris, L. \& Moore, H. P. (I943). F. Nutr. 25, 7.

Wright, R. C. \& Scott, E. M. (1954). F. biol. Chem. 206, 725.

\section{Dietary factors influencing nitrogen balance}

By D. S. Miller, Queen Elizabeth College, University of London, London, $W 8$ and P. R. Payne, Human Nutrition Research Unit, National Institute for Medical Research, The Ridgeway, Mill Hill, London, $\mathrm{NW}_{7}$

It is the purpose of this paper to provide, in so far as it is possible, an integrated view of the interrelationships between nutrients as they affect nitrogen balance. The literature abounds with data described in qualitative terms and an attempt has been made here to fit them into a unified scheme. In doing so we may have been guilty of oversimplification, but such generalizations are valuable in that they can lead to the quantitative solution of practical nutritional problems, for example that of (I) the best utilization of limited supplies of foodstuffs to meet the needs of the vulnerable groups of a population which has a low purchasing power, or (2) that of the design of least-cost diets for animal production, particularly for pigs and poultry.

\section{List of terms used}

$\triangle B=$ nitrogen balance in $\mathrm{mg} / \mathrm{day} \mathrm{kg}^{0.73}$ body-weight

$I=$ nitrogen intake in $\mathrm{mg} / \mathrm{day} \mathrm{kg}^{0.73}$ body-weight $=0 .{ }_{4} \mathrm{PC}$

$\Theta=$ net protein utilization (NPU) expressed as a fraction

$M=$ nitrogen used for maintenance $=250 \mathrm{mg} \mathrm{N} /$ day $\mathrm{kg}^{\mathbf{0 . 7 3}}$ body-weight

$S=$ protein score expressed as a fraction

$k=$ constant $=0.019$

$P=$ protein calories as $\%$ of total calories

$C=$ calorie intake in $\mathrm{kcal} / \mathrm{day} \mathrm{kg}^{\mathbf{0 . 7 3}}$ body-weight

$C_{\mathrm{B}}=$ energy for basal metabolism $=70 \mathrm{kcal} /$ day $\mathrm{kg}^{0.73}$ body-weight 